Nauki ekonomiczne w XXI wieku - wyzwania, dylematy, perspektywy

ISSN 1899-3192

Międzynarodowe stosunki gospodarcze

\title{
Pawel Śliwiński
}

Uniwersytet Ekonomiczny w Poznaniu

e-mail: pawel.sliwinski@ue.poznan.pl

\section{KRYZYS ZADEUŻENIA PORTORYKO \\ JAKO PRZYKLAD KRYZYSU W KRAJU \\ PERYFERYJNYM UNII WALUTOWEJ}

\section{PUERTO RICO DEBT CRISIS AS AN EXAMPLE OF THE CRISIS IN THE PERIPHERAL AREA OF A CURRENCY UNION}

DOI: 10.15611/pn.2017.498.32

JEL Classification: F33, F34, F45.

Streszczenie: W artykule przedstawiono przyczyny zadłużenia Portoryko oraz strategie wyjścia z kryzysu, będącego przykładem kryzysu w kraju peryferyjnym unii walutowej. Analizowana jest teza, że występowanie niektórych uwarunkowań uznanych w teorii za podstawę tzw. optymalnych obszarów walutowych (scentralizowana polityka budżetowa, nieograniczona mobilność pracy) może okazać się destabilizujące w przypadku dużych różnic w strukturze gospodarek ,jądra” i peryferii unii walutowej. Z uwagi na to, że przyczyną kryzysu zadłużenia Portoryko były problemy strukturalne tej gospodarki, które przyczyniły się do wystąpienia nadmiernego zadłużenia sektora publicznego wyspy, wyniki analizy wskazują, że strategia wyjścia z kryzysu zadłużenia powinna obejmować kompleksowe podejście, obejmujące - poza reformami strukturalnymi zwiększającymi konkurencyjność wyspy - również konsolidację fiskalną oraz restrukturyzację zadłużenia.

Słowa kluczowe: unia walutowa, kryzys zadłużenia, kryzys w Portoryko, optymalny obszar walutowy.

Summary: The article presents the causes and the proposals how to solve the debt crisis in Puerto Rico which is an example of the crisis in the periphery of a monetary union. Hypothesis analysed in this article is the thesis that the occurrence of some of the conditions considered in theory as the basis for optimum currency areas (centralized fiscal policy, unrestricted labour mobility) could be sometimes destabilizing in the case of large differences in the structure of economies of so called "core" and a periphery of the monetary union. The analysis results indicated that due to the fact that the cause of the debt crisis of Puerto Rico were structural problems in its economy, which contributed to the occurrence of excessive public sector debt, exit strategy from the debt crisis should include a comprehensive approach covering the structural reforms that increase the competitiveness of the island, the fiscal consolidation and debt restructuring.

Keywords: currency union, debt crisis, Puerto Rico crisis, optimal currency area. 


\section{Wstęp}

Kryzysy w krajach peryferyjnych Europejskiej Unii Monetarnej zwróciły uwagę na występujące asymetrie w uniach walutowych ${ }^{1}$. Okazuje się, że teoretyczne warunki występowania tzw. optymalnych obszarów walutowych ${ }^{2}$ nie zawsze (a właściwie rzadko) są spełnione w rzeczywistości, co przyczyniać się może do występowania nierównowagi wewnętrznej i/lub zewnętrznej w niektórych krajach członkowskich unii.

W przypadku asymetrycznych unii monetarnych korzyści wynikające z członkostwa w unii mogą być umniejszane przez koszty usztywnienia kursu walutowego, z których najważniejszym wydaje się utrata swobody w prowadzeniu polityki monetarnej i kursowej, mającej na celu m.in. reagowanie na pojawiające się wewnętrzne i zewnętrzne szoki. W sytuacji ekstremalnej asymetryczna unia walutowa nie spełnia kryterium optymalnego obszaru walutowego w rozumieniu Grubela jako obszaru, w którym kraje (regiony) przyczyniają się do wzrostu dobrobytu swoich mieszkańców powyżej wielkości, która miałaby miejsce, gdyby kraje (obszary) nie wchodziły w skład unii [Grubel 1970].

$\mathrm{Na}$ asymetryczność unii można patrzeć m.in. z perspektywy różnic: a) w poziomie rozwoju poszczególnych krajów (regionów) mierzonych np. wielkością PKB (PNB) per capita, b) w strukturze gospodarek, c) w otwartości w handlu zagranicznym, d) w stopniu rozwoju rynku finansowego, e) w poziomie inflacji, f) w strukturze bilansu płatniczego czy g) w wielkości zadłużenia krajowego i zagranicznego. Występowanie wskazanych różnic powoduje, że unie walutowe nie są jednorodnymi obszarami, lecz składają się tzw. ,jądra” oraz peryferii różniących się względem siebie m.in. poziomem rozwoju ekonomicznego. W ostatnich latach zauważyć można większą skłonność obszarów peryferyjnych do występowania zaburzeń (kryzysów) ekonomicznych, które spowalniają konwergencję dochodów na mieszkańca (a czasami przyczyniają się okresowo nawet do dywergencji tych dochodów). Temat ten analizowany jest w Polsce z reguły w kontekście kryzysu zadłużenia w Grecji (lub problemów gospodarczych Portugalii, a wcześniej Irlandii i Hiszpanii) (np. [Nowak 2012; Sporek 2013; Bilski, Janicka 2015]).

Celem artykułu jest analiza przyczyn oraz propozycji rozwiązań wciąż stosunkowo mało znanego w Polsce kryzysu zadłużenia Portoryko, wyspy będącej częścią unii dolarowej. W pracy sformułowano następujące hipotezy badawcze. Hipoteza pierwsza (H1): występowanie niektórych uwarunkowań uznanych w teorii za podstawę tzw. optymalnych obszarów (scentralizowana polityka budżetowa, nieogra-

\footnotetext{
${ }^{1}$ W pracy użyto terminu „unia walutowa” jako obszaru charakteryzującego się rezygnacją (dobrowolną lub przymusową) ze swoich walut narodowych na rzecz wspólnej waluty (por. [Visser 2007, s. 180]).

${ }^{2}$ Szerzej na temat różnych koncepcji teoretycznych, opisujących warunki niezbędne dla optymalnych obszarów walutowych, m.in.: Visser [2007] i Tchorek [2014].
} 
niczona mobilność pracy) walutowych może okazać się destabilizujące w procesie konwergencji w przypadku występowania dużych różnic w strukturze gospodarek ,jądra" i peryferii unii walutowej. Hipoteza druga (H2): przyczyną kryzysu zadłużenia Portoryko były problemy strukturalne gospodarki Portoryko, które wraz z permanentnie niezrównoważoną polityką fiskalną doprowadziły do wystąpienia nadmiernego zadłużenia sektora publicznego. Hipoteza trzecia (H3): strategia wyjścia z kryzysu zadłużenia Portoryko powinna obejmować kompleksowe podejście, obejmujące poza reformami strukturalnymi zwiększającymi konkurencyjność wyspy również konsolidację fiskalną oraz restrukturyzację zadłużenia.

\section{Portoryko jako obszar peryferyjny unii walutowej}

Portoryko, jedna z wysp Ameryki Środkowej, zaliczana jest do terytoriów nieinkorporowanych Stanów Zjednoczonych o statucie wspólnoty (US Commonwealth) ${ }^{3}$. W wyniku wojny pomiędzy USA i Hiszpanią (1898) Stany Zjednoczone przejęły kontrolę m.in. nad Portoryko. Od tego czasu Portoryko jest terytorium zależnym od Stanów Zjednoczonych o dużej autonomii wewnętrznej ${ }^{4}$.

Wskutek decyzji amerykańskiego Kongresu z 1917 roku mieszkańcy Portoryko są obywatelami USA. Głową wyspy jest prezydent Stanów Zjednoczonych a Portorykańczycy podlegają amerykańskiemu systemowi prawnemu. Portoryko uzyskało jednak pewne przywileje, np. mieszkańcy nie płacą federalnych podatków od dochodów wytworzonych na wyspie.

Od 1900 roku walutą wyspy jest dolar amerykański ${ }^{5}$, bankiem emisyjnym dla obszaru walutowego, do którego należy Portoryko, jest amerykański bank centralny Fed, który decyduje m.in. o kształtowaniu się podaży pieniądza.

Portoryko spełnia kryterium kraju peryferyjnego dolarowej unii walutowej nie tylko z uwagi na swoje położenie. Krajem/obszarem peryferyjnym ${ }^{6}$ można nazwać Portoryko ze względu na jego stopień rozwoju ekonomicznego (rys. 1) oraz niestabilność ekonomiczną wyrażoną m.in. poprzez wysokie wskaźniki zadłużenia sektora publicznego w relacji do przychodów budżetowych oraz wyższą stopę bezrobocia (tabela 1).

\footnotetext{
${ }^{3}$ Podstawowe źródła o Portoryko zaczerpnięte zostały z Wikipedii: https://en.wikipedia.org/wiki/ Puerto_Rico (10.05.2016).

${ }^{4}$ Szerzej na temat historii gospodarczej i politycznej wyspy: [Dietz 1986].

${ }^{5} 12$ kwietnia 1900 roku Kongres Stanów Zjednoczonych uchwalił konwersję portorykańskiego peso na amerykańskie dolary według stałego kursu równego 1 peso $=0,60$ amerykańskiego dolara. Ustawa wprowadzała trzymiesięczny okres przejściowy, w którym obowiązywały obydwie waluty jako legalny środek płatniczy na wyspie. Szerzej: [Lenihan 1997, s. 51-54].

${ }^{6}$ Według Blueschkego i Necka [2011] unia monetarna jest asymetryczna, jeżeli składa się z jądra (core), charakteryzującego się niską relacją długu publicznego do PKB, oraz z bardziej zadłużonych peryferii. Arce, Hurtago i Thomas [2015] charakteryzują kraje peryferyjne szerzej, zakładając, że występuje w nich kombinacja wysokiego zadłużenia oraz dysfunkcji na rynku pracy oraz na rynku czynników produkcji.
} 


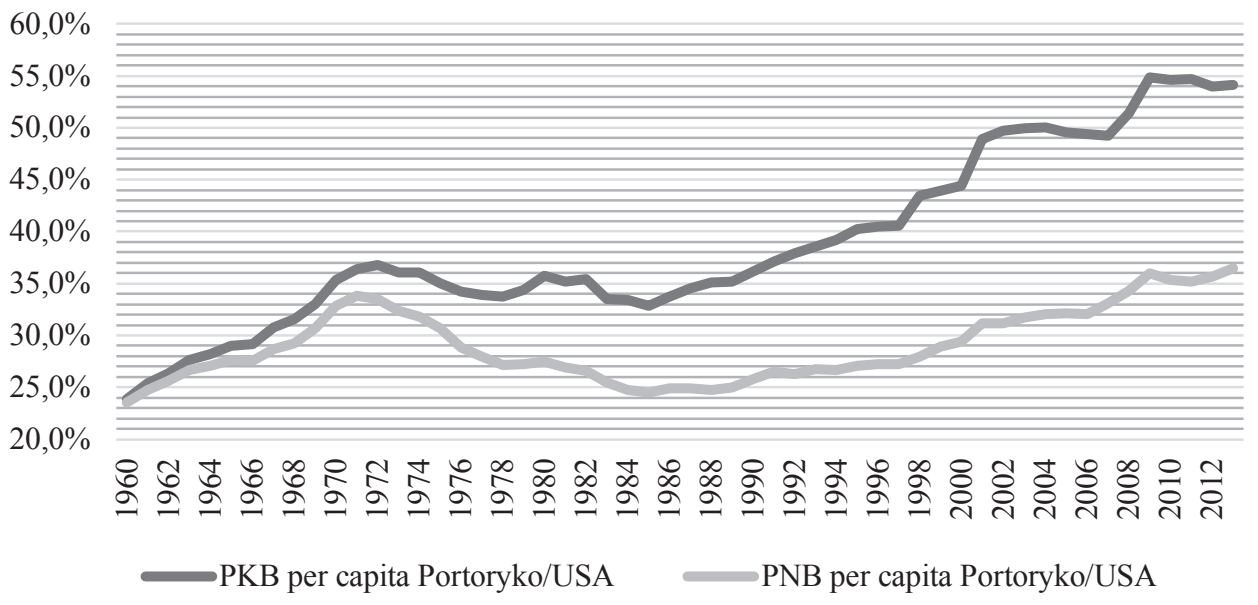

Rys. 1. PKB i PNB per capita Portoryko w relacji do PKB i PNB per capita USA w latach 1960-2013 (w \%)

Źródło: opracowanie własne na podstawie bazy danych Banku Światowego WDI, http://data.worldbank.org/ (15.09.2017).

Tabela 1. Wybrane dane na temat gospodarek Portoryko i USA

\begin{tabular}{|l|r|r|r|}
\hline \multicolumn{1}{|c|}{ Wyszczególnienie } & Data & Portoryko & \multicolumn{1}{c|}{ USA } \\
\hline PKB (mld USD) & 2013 & 103,7 & 17091,2 \\
\hline PNB (mld USD) & 2013 & 70,7 & 16768,1 \\
\hline PKB per capita (USD) & 2013 & 28682 & 52980 \\
\hline PNB per capita (USD) & 2013 & 19673 & 54001 \\
\hline Wzrost PKB (dane za rok) & 2016 & $-1,1 \%$ & $3 \%$ \\
\hline Populacja (mln) & 2016 & 3,47 & 324 \\
\hline Stopa zatrudnienia (do całości populacji) & lip-17 & $35,6 \%$ & $62,9 \%$ \\
\hline Stopa bezrobocia & lip-17 & $10,4 \%$ & $4,3 \%$ \\
\hline Indeks konkurencyjności (miejsce w świecie) & gru-15 & 32 & 3 \\
\hline Łatwość prowadzenia biznesu (miejsce w świecie) & gru-16 & 55 & 8 \\
\hline Rating (S\&P) & lip-17 & $\mathrm{D}$ & $\mathrm{AA}+$ \\
\hline Inflacja (CPI) & lip-17 & $1,7 \%$ & $1,7 \%$ \\
\hline Oprocentowanie 10-letnich obligacji skarbowych & cze- 15 & $10,5 \%$ & $2,36 \%$ \\
\hline Dług publiczny, w tym samorządów (mld USD) & 2014 & 67,3 & 20776,9 \\
\hline Dług publiczny/PKB & 2014 & $65 \%$ & $119 \%$ \\
\hline Dług publiczny/przychody budżetowe & 2014 & $6876 \%$ & $348 \%$ \\
\hline
\end{tabular}

Źródło: opracowanie własne na podstawie bazy danych Banku Światowego WDI, http://data.worldbank.org/ (15.09.2017); Stooq.pl, http://stooq.pl/q/?s=10usy.b\&c=1y\&t=c\&a $=\ln \& b=1$ (15.09.2017); Trading-economics.com, http://www.tradingeconomics.com/puerto-rico/indicators (15.09.2017) oraz Government Development Bank for Puerto Rico, http://www.gdb-pur. com/economy/pr-monthly-economic-indicators-time-series.html (4.07.2017). 


\section{Kryzys zadłużenia Portoryko i jego przyczyny}

Brak spłaty obligacji przez kontrolowaną przez władze wyspy spółkę Public Finance Corporation $^{7}$ w sierpniu 2015 roku rozbudził obawy na rynku finansowym o przyszłe płatności obligacji emitowanych lub gwarantowanych przez Portoryko. Ceny obligacji publicznych wyspy spadały już od 2013 roku, a w lutym 2014 roku agencje ratingowe Fitch Ratings, Moody's Investors Service i Standard \& Poor's oceniły dług publiczny Portoryko poniżej poziomu inwestycyjnego.

W ostatnich 15 latach dług publiczny Portoryko rósł w każdym roku. Obecne (2017) zadłużenie sektora publicznego Portoryko wynosi powyżej 74 mld USD [Bloomberg 2017]. Co ciekawe, dług publiczny Portoryko wynika głównie z zadłużenia władz centralnych wyspy oraz trzech największych przedsiębiorstw publicznych: przedsiębiorstwa wodno-kanalizacyjnego PRASA, państwowej firmy energetycznej PREPA oraz przedsiębiorstwa zarządzającego autostradami HTA. Na koniec 2014 roku dług publiczny stanowił 65\% PKB i blisko 100\% PNB wyspy. Zadłużenie sektora publicznego wyspy z podziałem na zadłużenie władz centralnych, jednostek samorządowych oraz przedsiębiorstw publicznych przedstawia rys. 2 .

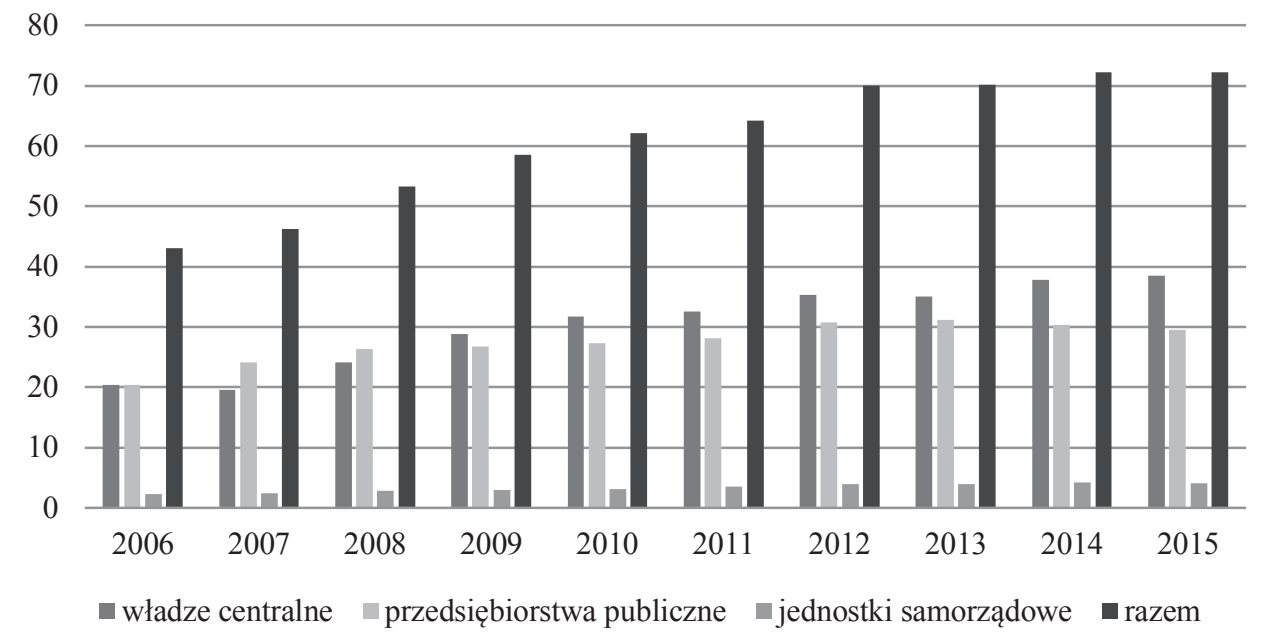

Rys. 2. Dług publiczny Portoryko w latach 2006-2015 (w mln USD)

Źródło: opracowanie własne na podstawie [Joffe, Martinez 2016].

${ }^{7}$ Nie spłacono wówczas zobowiązań z tytułu wyemitowanych obligacji na kwotę 58 mln USD. Spółka Public Financing Corporation jest spółką córką banku Government Development Bank (GDB). GDB jest m.in. emitentem portorykańskich obligacji skarbowych, agentem fiskalnym i doradcą finansowym władz Portoryko. 
Stałe deficyty odzwierciedlały czynniki instytucjonalne [Krueger i in. 2015, s. 9-10]: a) zbyt optymistyczne założenia budżetowe, w tym szczególnie dotyczące projekcji przychodów, b) brak instrumentów kontroli wydatków i narastanie zobowiązań, c) brak płynności pieniężnej i wynikający z tego system zachęt podatkowych obniżających de facto podstawę podatkową ${ }^{8}$ d) system ulg i zwolnień podatkowych w celu przyciągnięcia inwestycji. Poza wskazanymi czynnikami należy wymienić dodatkowe uwarunkowania, które przyczyniły się do pojawienia nadmiernego zadłużenia Portoryko (szerzej: [Joffe i Martinez 2016]). Jednym z atrybutów niezależności wyspy jest niepodleganie rozdziałowi 9 przepisów prawa upadłościowego, umożliwiających restrukturyzację długów jednostek samorządowych pod okiem sądu federalnego. $Z$ jednej strony teoretycznie zwiększało to ryzyko dla nabywców obligacji Portoryko (oraz dla władz wyspy, na których wymuszało to obsługę długu w całości nawet w sytuacji, w której inne jednostki byłyby chronione procedurami dotyczącymi bankructwa), z drugiej strony przyczyniało się do występowania pokusy nadużycia (moral hazard) w związku z funkcjonowaniem wyspy w strefie dolara amerykańskiego i oczekiwaniem przez pożyczkodawców interwencji ze strony amerykańskiego banku centralnego jako pożyczkodawcy ostatniej instancji w celu ewentualnego oddłużenia tego terytorium nieinkorporowanego USA. Mimo zwiększającego się zadłużenia Portoryko (w ciągu ostatnich 15 lat zwiększyło się ono około trzech razy) popularność obligacji portorykańskich w portfelach funduszy inwestycyjnych rosła również z uwagi na wyższe ich oprocentowanie w stosunku do emitowanych na kontynencie amerykańskim obligacji skarbowych i komunalnych oraz z uwagi na istnienie korzyści podatkowych z tytułu ich posiadania.

Istnienie wskazanych czynników instytucjonalnych było bodźcem sprzyjającym wzrostowi zadłużenia. Nie były one jednak bezpośrednią przyczyną kryzysu zadłużenia wyspy. Jest on przede wszystkim rezultatem problemów strukturalnych gospodarki Portoryko.

Proces konwergencji, który zgodnie z teorią wspólnych obszarów walutowych jest oczekiwany w uboższych ich obszarach, w nawiązaniu do rys. 1, spowolnił na początku lat 80. ubiegłego wieku9. Zbiegło się to z wyrównaniem w 1983 roku reguły płacy minimalnej obowiązującej w Portoryko i USA. Castillo-Freeman i Freeman [1992] wskazują, że w rezultacie m.in.: a) zatrudnienie na wyspie zmniejszyło o $8-10 \%$, b) nastąpiła realokacja zatrudnienia pomiędzy sektorami gospodarki, przy czym największy odpływ miał miejsce z sektorów charakteryzujących się niskimi płacami, kształtującymi się przed 1983 rokiem poniżej minimum w części kontynentalnej USA, c) nastąpiło zwiększenie migracji z Portoryko na kontynent ${ }^{10}$, przy

\footnotetext{
${ }^{8}$ M.in. zniżki dla podatników płacących podatki w postaci zaliczek na poczet przewidywanych zobowiązań podatkowych oraz amnestie podatkowe.

${ }^{9}$ Proces konwergencji liczony stosunkiem PKB per capita Portoryko i USA. Z kolei proces dywergencji liczonej stosunkiem PNB per capita kontynuował swój trend rozpoczęty na początku lat 70.

${ }^{10} \mathrm{~W}$ latach 80 . XX wieku migracja na kontynent wynosiła średniorocznie $1 \%$ ludności wyspy, podczas gdy w latach 70 . średniorocznie było to $0,3 \%$.
} 
czym dotyczyło to w większym stopniu osób o niskich kwalifikacjach. Skutkiem znacznego zwiększenia płacy minimalnej było zatem zmniejszenie podaży pracy zarówno w krótkim, jak i w dłuższym horyzoncie czasowym.

Okres konwergencji liczonej stosunkiem realnego PKB per capita pomiędzy wyspą i USA natrafił na kolejne przeszkody na początku pierwszej dekady XXI wieku. Wzrost PKB per capita utrzymywał się do tego czasu m.in. dzięki subsydiom podatkowym dla amerykańskich kontynentalnych firm farmaceutycznych [Gros 2015, s. 7 $]^{11}$. W 2006 roku zakończyły się ulgi podatkowe dla firm spoza Portoryko, co zbiegło się z recesją na wyspie. Od tego czasu wyspa pogrążyła się w stagnacji, a negatywny wzrost gospodarczy wynikał w dużej mierze z problemów leżących po stronie podażowej ${ }^{12}$ [Krueger i in. 2015, s. 6-8]. Są to:

- niepełne wykorzystanie siły roboczej - tylko $40 \%$ ludności jest zatrudnione lub poszukuje pracy w porównaniu z $63 \%$ na kontynencie amerykańskim ${ }^{13}$,

- wysokie koszty pracy - zatrudnienie w pełnym wymiarze czasu generuje $77 \%$ dochodu per capita na wyspie w porównaniu z $28 \%$ na kontynencie,

- rozbudowany system opieki społecznej - zasiłki często przekraczają wysokość płacy minimalnej, zniechęcając do podjęcia pracy,

- odpływ ludności w wyniku migracji na kontynent - Portoryko jest jedynym terytorium USA o ujemnej dynamice wzrostu ludności,

- wysokie ceny energii elektrycznej - energia elektryczna jest wytwarzana i dystrybuowana przez nieefektywne przedsiębiorstwo publiczne PREPA, korzystające z przestarzałej technologii i charakteryzujące się znacznym przerostem zatrudnienia; w rezultacie ceny energii elektrycznej są kilkukrotnie wyższe niż na kontynencie, co osłabia konkurencyjność kosztową firm lokowanych na wyspie,

- wysokie koszty transportu - z uwagi na swe położenie oraz ze względu na obowiązywanie ustawy Jonesa, nakazującej dostarczanie towarów do i z portów amerykańskich na statkach pod banderą USA z amerykańską załogą; szacuje się, że koszty transportu na i z wyspy są co najmniej dwukrotnie wyższe niż w przypadku sąsiednich wysp,

- bariery dla działalności gospodarczej - w 2015 roku Portoryko zajmowało 189. pozycję w rankingu Doing Business Banku Światowego, podczas gdy USA - 7. [Doing Business 2016].

\footnotetext{
${ }^{11}$ Szybszy wzrost PKB per capita w stosunku do PNB per capita wynika z tego, że zyski firm zagranicznych działających na wyspie zaliczane są do PKB, ale nie są zaliczane do PNB.

${ }^{12}$ Niski poziom zatrudnienia oraz zmniejszanie się liczby ludności wpływają również na zmniejszanie popytu, ograniczając przez to konsumpcję, jak również pośrednio inwestycje, przyczyniając się w konsekwencji do zmniejszania się produktu krajowego wyspy.

${ }^{13}$ Duża część pracuje jednak w szarej strefie, która nie jest objęta statystyką.
} 


\section{Strategia wyjścia z kryzysu zadłużenia Portoryko}

Najprostszą radą w procesie restrukturyzacji długu publicznego jest zrównoważenie finansów publicznych poprzez eliminowanie deficytów publicznych. Dotychczasowe próby były jednak nieudane ${ }^{14}$. Koncentrowały się one bowiem na problemie zrównoważenia deficytów fiskalnych, a nie na problemie wzrostu gospodarczego. Doraźna presja na kolejne cięcia w wydatkach oraz zwiększenie wpływów budżetowych wskutek zwiększenia podatków zgłaszane były również w 2015 roku, w okresie zaprzestania spłacania zadłużenia przez Portoryko. Rzecznikami takiego rozwiązania były fundusze hedgingowe, które lobbowały za dalszym zaciskaniem pasa i szybkimi reformami ${ }^{15}$. W swoim opracowaniu Fajgenbaum, Guzman i Loser [2015] wskazywali, że reformy fiskalne, skutkujące zmniejszeniem wydatków w wysokości 2 mld USD rocznie do 2020 roku i 2,5 mld USD do 2025 roku (dzięki m.in. zamrożeniu niektórych wydatków budżetowych, zmniejszeniu liczby nauczycieli, zmniejszeniu dotacji dla University of Puerto Rico oraz zmniejszeniu dodatkowych świadczeń medycznych) oraz zwiększeniem przychodów do budżetu w wysokości 3 mld USD do 2020 roku i 4 mld USD do 2025 roku, wraz z podjętymi reformami strukturalnymi umożliwiłoby generowanie przez Portoryko stałej nadwyżki budżetowej.

Krótka analiza przyczyn kryzysu zadłużenia Portoryko wskazuje jednak, że wynika on z połączenia problemów strukturalnych gospodarki wyspy z permanentnie niezrównoważoną polityką fiskalną. Podstawą do poprawy sytuacji jest zatem doprowadzenie do trwałego ożywienia gospodarczego, co wydaje się niemożliwe bez reform wzmacniających stronę podażową. Wiele z nich wymagać będzie podjęcia decyzji politycznych naprawiających przeszkody zwiększające koszty prowadzenia działalności na wyspie i wstrzymujące jej rozwój. Najważniejsze dotyczą reform przyczyniających się do przywrócenia konkurencyjności cenowej wyspy (wobec braku możliwości wykorzystania mechanizmu kursu walutowego jako automatycznego stabilizatora pozwalającego osiągnąć równowagę ekonomiczną) poprzez obniżenie relatywnie wysokich kosztów produkcji (pracy, energii i transportu). Lokalne przepisy prawa pracy leżą w gestii władz wyspy. Ale te, które dotyczą zmniejszenia

\footnotetext{
${ }^{14}$ Przykłady takich działań to: wprowadzenie podatku od sprzedaży w 2006 roku, zmniejszenie zatrudnienia w administracji w 2009 roku, reforma emerytur nauczycieli i pracowników sektora publicznego w 2013 roku oraz wprowadzenie podatku naftowego w 2014 roku.

${ }^{15}$ Alternatywą miałoby być zwrócenie się obligatariuszy do sądów i niekontrolowana upadłość finansowa Portoryko, skutkująca [Fajgenbaum i in. 2015]: a) upadkiem wiarygodności finansowej wyspy, ucieczką inwestorów i długotrwałą recesją, b) brakiem możliwości korzystania z finansowania zewnętrznego, c) dużymi kosztami prawnymi obsługi procesu upadłości wobec braku formalnej możliwości bankructwa wyspy oraz skomplikowanej struktury obligacji publicznych wyemitowanych przez prawie 20 emitentów, d) nieprzewidywalnych w skutkach problemów finansowych największych banków na wyspie, e) stratami wierzycieli mających siedzibę na wyspie, którzy stanowią dużą część posiadaczy obligacji.
} 
wysokości minimalnej płacy oraz świadczeń socjalnych czy zwolnienia z ustawy Jonesa, leżą z kolei w gestii władz federalnych.

Reformy zmierzające do poprawienia konkurencyjności wyspy nie mogą obejmować tylko formalnych zmian legislacyjnych. Dla zwiększenia zatrudnienia niezbędne jest między innymi usunięcie czynników zniechęcających do zatrudnienia nowych pracowników oraz zwiększających koszty produkcji, takich jak wysokie koszty energii. Wdrożenie reform wymaga również czasu, zarówno ze względu na proces legislacyjny, jak i na dostosowanie się gospodarki do ewentualnych zmian. Czas jest również niezbędny do zmiany postrzegania procesu reform przez przedsiębiorców i konsumentów jako reform trwałych, przywracających wiarygodny, stabilny, solidny i długoterminowy wzrost gospodarczy. W okresie wdrażania reform niezbędna jest dodatkowa pomoc władz federalnych USA w celu „kupienia” czasu niezbędnego do wdrożenia reform skutkujących ożywieniem gospodarczym i w konsekwencji poszerzeniem bazy podatkowej.

Na początku maja 2017 roku Portoryko złożyło wniosek do Sądu Federalnego o ochronę przed wierzycielami oraz restrukturyzację swojego zadłużenia. Była to odpowiedź m.in. na pozwy o wyegzekwowanie roszczeń wynikających z niespłacenia obligacji, złożone przez niektórych wierzycieli. Władze wyspy już wcześniej postulowały częściową redukcję zadłużenia wyspy [Austin 2016, s. 5-6]. Mogłaby ona polegać np. na dobrowolnej wymianie już wyemitowanych obligacji (zarówno skarbowych, jak i emitowanych przez przedsiębiorstwa publiczne wyspy) na „nowe” obligacje o mniejszej wartości nominalnej, niższym kuponie odsetkowym i późniejszym terminie spłaty. Sukces negocjacji wymaga jednak odbudowy wiarygodności władz wyspy zarówno w zakresie prowadzonych reform strukturalnych, jak i przejrzystości reformy finansów publicznych.

\section{Zakończenie}

Portoryko ma szanse wyjść z trudnej sytuacji kryzysowej. Poza wskazywanymi w artykule wadami posiada wiele zalet, które dobrze wykorzystane mogą pomóc tej gospodarce powrócić na ścieżkę zrównoważonego wzrostu. Jedną z najważniejszych jest to, że Portoryko pod względem ekonomicznym może być traktowane jako integralna część Stanów Zjednoczonych. Może zatem (i powinna) wykorzystać fakt, iż posiada stabilną walutę, system prawny gwarantujący prawa własności, wsparcie federalne m.in. w zakresie systemu bankowego, edukacji, opieki społecznej oraz w zakresie obronności. Portoryko posiada też własne atuty, które odpowiednio wykorzystane mogą pomóc jej w pozyskiwaniu inwestorów, np. dwujęzyczną, wykształconą populację. Nie bez znaczenia jest też jej położenie i klimat, które powinny być wykorzystane do rozwoju tej tropikalnej wyspy jako popularnego kierunku turystycznego dla kontynentalnej Ameryki.

Ponieważ przyczyną kryzysu zadłużenia Portoryko były problemy strukturalne gospodarki, które wraz z permanentnie niezrównoważoną polityką fiskalną dopro- 
wadziły do wystąpienia nadmiernego zadłużenia sektora publicznego (hipoteza H2), wyjście Portoryko ze spirali zadłużenia wydaje się możliwe tylko dzięki kompleksowemu podejściu (hipoteza H3), obejmującemu: a) działania zmierzające do konsolidacji fiskalnej mającej na celu wyeliminowanie deficytów fiskalnych poprzez działania zarówno po stronie wydatków, jak i dochodów, b) wprowadzenie instytucjonalnych form kontroli finansów publicznych, c) wprowadzenie reform strukturalnych poprawiających konkurencyjność oraz d) restrukturyzację zadłużenia umożliwiającą wyjście ze spirali zwiększającego się z upływem czasu zadłużenia.

Kolejnym wnioskiem, który można sformułować analizując portorykański kryzys zadłużenia, jest to, że niektóre teoretyczne warunki niezbędne do utworzenia optymalnego obszaru walutowego mogą być „bronią obosiecznym”, w pewnych warunkach bowiem, zamiast stymulować konwergencję w ramach unii, może doprowadzić do pogłębienia się procesu dywergencji.

W teorii optymalnych obszarów walutowych podkreśla się, że pełne korzyści z członkostwa $\mathrm{w}$ obszarze walutowym osiąga się m.in. w warunkach scentralizowanej polityki budżetowej oraz w warunkach nieograniczonej mobilności pracy. Mobilność pracy w ramach amerykańskiej unii walutowej ${ }^{16}$ przyczyniła się do zmniejszenia skali bezrobocia na wyspie, co miało z pewnością w krótkim okresie pozytywny wpływ na budżet (mniejsze obciążenie budżetu poprzez zmniejszenie skali wydatków socjalnych), ale w dłuższym okresie stanowiło szok podażowy, ograniczający możliwości wzrostu dochodu narodowego Portoryko, co w pośredni sposób przyczyniło się do pogorszenia wskaźników zadłużenia wyspy.

Również trudno zgodzić się z opinią, że centralna polityka fiskalna może rozwiązywać problemy terenów peryferyjnych w sytuacji nierozwiązanych problemów strukturalnych. Środki pieniężne z budżetu federalnego trafiają bezpośrednio do budżetu Portoryko (stanowią ponad 1/3 jego przychodów) oraz do obywateli wyspy. Analizując sytuację gospodarczą Portoryko, można stwierdzić, że środki te, zamiast wspomagać wzrost gospodarczy kraju, przyczyniają się do zwiększania dysproporcji pomiędzy wyspą a kontynentem (przejawem jest zwiększający się udział środków federalnych w budżecie Portoryko). Nie wymusiły bowiem u władz ani u obywateli Portoryko konieczności prowadzenia polityki nakierowanej na wzrost gospodarczy, a w wielu przypadkach uzależniły egzystencję wyspy oraz jej obywateli od środków pochodzących z budżetu federalnego ${ }^{17}$.

Na marginesie można zadać pytanie, czy poza teorią w ogóle istnieje optymalny obszar walutowy. Poszczególne kraje wchodzące w skład unii walutowych charakteryzują się zazwyczaj dużymi różnicami w stopniu rozwoju gospodarczego. Pomiędzy poziomem dobrobytu w krajach/obszarach wysoko rozwiniętych (Stany

${ }^{16} \mathrm{~W}$ ostatniej dekadzie wielkość emigracji na kontynent wynosiła średniorocznie ponad 1\% populacji wyspy. Obecnie na wyspie mieszka około 3,5 mln Portorykańczyków, podczas gdy na kontynencie amerykańskim mieszka ich około $5 \mathrm{mln}$ [Hispanicfederation 2015, s. 10-11].

${ }^{17}$ Transfery fiskalne stanowią około $20 \%$ PKB Portoryko, podczas gdy subsydia z budżetu federalnego $8 \%$. 
Zjednoczone, a w Europie: Niemcy i Holandia) a poziomem dobrobytu w krajach słabiej rozwiniętymi (Portoryko czy Portugalia i Grecja) występują duże dysproporcje (podobnie analizować można duże kraje, których poszczególne rejony nie są homogeniczne). Przykład Portoryko pokazuje, że różnice te mogą się pogłębiać na przestrzeni lat (szczególnie jeżeli będzie się je obliczać w wartościach bezwzględnych), wbrew leżącym u podstaw założeniom o oczekiwanej konwergencji dochodów per capita. Wynika to m.in. z braku automatycznego przepływu czynników produkcji z kraju o wyższych kosztach do kraju o niższych kosztach. Tym bardziej że tak jak w analizowanym przypadku Portoryko, z czasem obszary uboższe (z definicji charakteryzujące się niższymi kosztami produkcji) mogą tracić swą przewagę w zakresie konkurencyjności cenowej wraz z ujednolicaniem niektórych przepisów funkcjonujących w ramach unii, powodujących zwiększania się kosztów produkcji bez idącej za tym zmiany wydajności pracy.

Na przykładzie Portoryko można zatem zauważyć, że występowanie wskazanych wyżej uwarunkowań uznanych w teorii za podstawę tzw. optymalnych obszarów (scentralizowana polityka budżetowa, nieograniczona mobilność pracy) walutowych może okazać się destabilizujące w procesie konwergencji w przypadku występowania dużych różnic w strukturze gospodarek ,jąadra" i peryferii unii walutowej (hipoteza H1).

\section{Literatura}

Arce O., Hurtago S., Thomas C., 2015, Policy Spillover and Synergies in a Monetary Union, Working Paper, https://www.ecb.europa.eu/pub/conferences/shared/pdf /20151105_challenges/20151105 Challenges-8-Thomas.pdf (2.06.2017).

Austin D.A., 2016, Puerto Rico's Current Fiscal Challenges, Congressional Research Service Report, https://fas.org/sgp/crs/row/R44095.pdf (2.06.2017).

Bilski J., Janicka M., 2015, Kryzys strefy euro. Przypadek Grecji, Studia Prawno-Ekonomiczne, t. XCVII, s. 199-215.

Bloomberg, 2007, Puerto Rico Files for Historic \$70 Billion Debt Restructuring, https://www.bloomberg.com/news/articles/2017-05-03/puerto-rico-governor-wants-board-to-file-bankruptcy-likecase (4.05.2017).

Blueschke D., Neck R., 2011, “Core” and "periphery” in a Monetary Union. A macroeconomic policy game, International Advances in Economic Research, 17(3), s. 334-346

Castillo-Freeman A.J., Freeman R.B., 1992, When the Minimum Wage Really Bites: The Effect of the U.S.-Level Minimum on Puerto Rico, [w:] Borjas G.J., Freeman R.B. (eds.), Immigration and the Workforce: Economic Consequences for the United States and Source Areas, NBER, University of Chicago Press, s. 177-211.

Dietz J.L., 1986, Economic History of Puerto Rico, Princeton University Press, Princeton.

Doing Business, 2016, Measuring Regulatory Quality and Efficiency, The World Bank.

Fajgenbaum J., Guzman J., Loser C., 2015, For Puerto Rico, There is a Better Way. A Second Look at the Commonwealth's Finances and Options Going Forward, http://www.valuewalk.com/wpcontent/uploads/2015/07/For-Puerto-Rico-There-is-a-Better-Way.pdf (2.05.2017).

Gros D., 2015, Puerto Rico and Greece: A Tale of two defaults in a monetary union, Centre for European Policy Studies CEPS, 
Grubel H.G., 1970, The theory of optimum currency areas, Canadian Journal of Economics/Revue canadienne d'Economique, 3 (2).

Hispanicfederation, 2015, Puerto Rico's Economic Crises: Overview and Recommendations for Action, http://hispanicfederation.org/images/pdf/hfprpolicy2015.pdf (2.06.2017).

https://www.ceps.eu/system/files/HLB5_DG_PuertoRico_0.pdf (12.06.2017).

Joffe M.D., Martinez J., 2016, Origins of the Puerto Rico Fiscal Crisis, Marcatus Research, https:// www.mercatus.org/system/files/Joffe-Puerto-Rico-Fiscal-Crisis-v1.pdf (2.06.2017).

Krueger A.O., Teja R., Wolfe A., 2015, Puerto Rico - A Way Forward, http://www.bgfpr.com/ documents/puertoricoawayforward.pdf (2.06.2017).

Lenihan N., 1997, The Legal Implications of the European Monetary Union Under US and New York Law, European Central Bank.

Nowak A.Z., 2012, Koniec strefy euro, Studia Europejskie, nr 1.

Puerto Rico Debt Crisis: Making Sense of the Debate, 2017, Bloomberg, https://www.bloomberg.com/ graphics/2017-puerto-rico-debt-crisis/ (3.09.2017).

Sporek T., 2013, Globalne konsekwencje kryzysu finansowego w Grecji, Studia Europejskie, nr 3.

Tchorek G., 2014, Teoretyczne podstawy integracji walutowej, [w:] Kowalewski P., Tchorek G., Górski J. (red.), Mechanizmy funkcjonowania strefy euro, Wydawnictwo Wolter Kluwer, Warszawa.

Velez G., 2015, Puerto Rico's Debt Crisis: Challenges and Opportunities. .

Visser H., 2007, A Guide to International Monetary Economics, Edward Elgar Publishing, Cheltenham - Northampton. 